\title{
THE INFLUENCE OF DORMITORY ARCHITECTURE ON RESIDENT BEHAVIOR
}

MARTIN HEILWEIL recently received a Ph.D. in the Social Psychology program at the University of Michigan, and is presently affiliated with Con-Dor Consulting, of Ann Arbor, Michigan.

It seems reasonable that such characteristics as traffic flow, propinquity, facilities used in common, and facilities used individually would all influence how people interact with each other. It seems reasonable that the adequacy of the facilities provided would encourage their use, the search for alternate sites, or the abandonment of various tasks. The presence and adequacy of such facilities influence the feelings of users, towards themselves in task-related activities, their co-workers and their tasks. It is particularly important to study dormitories for several reasons. Insofar as college is defined as structured around academic or intellectual activity, the informal context of the dormitory may allow for a more relaxed and less noticed input for change, an input that consequently may be more successful. It is also important to study dormitories because the influence of the architecture will last at least the forty years that are the usual terms of the dormitory mortgage, far longer than any administrator's tenure.

AUTHOR'S NOTE: Address all inquiries and requests for reprints to Martin Heilweil, 437 South Fifth Avenue, Ann Arbor, Michigan 48104.

Environment and Behavior, Vol. 5 No. 4, December 1973

(C) 1973 Sage Publications, Inc. 
The dormitory experience-the residence for many students for a year or two, half their college time, and the locale for most of their time and energies and activities-must be fully understood, to maximize the architectural potentials for the student and the university's general goals. The alternative is to leave things to chance, to intuition, and to custodial or visual rather than functional concerns.

Hayes (1932) reported on the need for functional and user-based housing design. The recent interest in functional environmental programming, however, derives from a very different source than a concern with student need's. Van der Ryn and Silverstein (1967) present in microcosm the dilemma facing university housing officials across the country which has caused consequent increase in environmental programming research.

In the fall of 1959, at the University of California at Berkeley, two high-rise towers for student housing were constructed, at a cost of $\$ 10$ million, housing some 400 students. By the fall of 1963 two more such towers were constructed and were greeted by long waiting lists of students. Within a year, however, notwithstanding the need for student housing, students moved out in such numbers as to create a vacancy rate of $10 \%$, and threaten the financial viability of the whole housing enterprise. Further construction was halted, and in response to unavoidable financial, rather than educational needs, the Regents authorized a user-based study of student housing needs. It is interesting to note Peterson's (1968) study of the sources of campus unrest during the 1967-1968 year. He found that while Vietnam generated the single greatest number of protests, the second issue was living-group regulations.

Jencks and Reisman (1962: 732), writing about Harvard, have described dormitories in a way that can serve to characterize much of American college housing.

At an average cost of roughly $\$ 4,000$ per student, the average student residence joins two students, two beds, two bureaus, two desks, two straight chairs, and two hundred square feet of floor in an attempt to produce enlightenment. 
Commenting on the space allotted per student, Riker (1956) notes that the same amount of space will serve to park two cars. Farmer (1964: 100) adds

that the room is one of hundreds of identical cells strung across endless corridors which reverberate with the rhythm of footsteps, the ringing of telephones, and the rush of modern plumbing. The focal point of the cell block is the gang toilet where the floor ressidents meet for a daily lesson in togetherness.

It can also be noted that the dormitories tend to have rooms distributed along both sides of long, straight corridors which are interrupted only to turn at right angles into other long, straight corridors. There are generally one or two bath areas where sinks, toilets, and showers are concentrated. Residents are grouped in batches of 25 to fifty, depending on local building and fire regulations, the whims of the architect, the placement of stairwells, and the often arbitrary assumptions as to what number constitutes the optimum for a resident staff member to counsel. Such groupings come to be called houses. Dorms come in high-rise and low-rise versions, looking like hotels, cottages, or semi-attached housing. They usually have centralized eating and recreation facilities. Ground floors tend to be occupied by formal lounges (which Van der Ryn and Silverstein, 1967, and others, have called "furniture showrooms"), by administrative offices, and occasionally by smaller "date rooms." Student reactions are those of flight, where not constrained by residence regulation, or the (rarely) higher costs in the local housing market. Sommer (1968a) has noted in his survey work that students clearly prefer worn and old housing, even when soundproofing is inferior, for the sake of other amenities such as freedom of access and travel, and personalizability. of the living area, among other features.

For convenience of discussion here, the dissatisfaction with dormitory life, insofar as it relates to architectural design rather than administrative style or regulation, can be divided into three general behavioral areas and a fourth nonbehavioral area. Those are (1) privacy and isolation versus enforced social interaction; 
(2) proximity and social relations; (3) study activities and (4 individualization. This is not an exhaustive list, and as will b seen, the borders between areas are permeable; but the division will be used because they provide some beginning typology 0 the ways in which environment influences behavior. Through a this discussion, the role of administration will be omitted, evel though that omission may seem to limit the utility o investigation of architecture.

\section{USER DESIGN FACTORS: AREAS OF STUDENT ACTIVITY}

\section{PRIVACY}

Rooms. Sommer and Peterson (1966) found that student spent much of their free time in their dormitories. Hsia (1968 found that result also. Van der Ryn and Silverstein (1967) cit as one of the major problems the eternal lack of privacy Students reported that there was simply no place to go to $b$ alone. Double rooms are clearly not suited. Students cannot b alone in their rooms because that is where their roommates are This need for occasional privacy may be foremost to thi generation of inward-exploring youth, but it is not new McDougall (1930: 242) has expressed what many others it college administration have articulated. The college student, $h$ says, "has no place where he can sit down in comfort with book and a pipe and possess his soul in quietude... no plac where he can express his taste and develop his personality."

Van der Ryn and Silverstein (1967) indicated that over hal of the respondents in their survey report roommate conflicts a one of their major adjustment difficulties. Sommer (1969a notes that in cases of conflict, the usual resolution is for th stronger of the two to subtly, or not so subtly, drive the weake roommate out of the room. Students can change rooms if thei problem is a specific roommate and there is alternate space rather than if their problem is a general preference for privacy Roommates who do transfer out thus create the uniqu situation where the most obnoxious and rigid of the two $i$ 
reinforced for his behavior by getting a double room for himself. The clear desirability of singles is further attested to by the fact that they are chosen first, and allocated on a seniority basis, with occasional exceptions among freshmen and female students who prefer doubles.

One usual resolution to the problem of privacy and incompatible roommates is staggered study and class schedules. Van der Ryn and Silverstein (1967) cite this arrangement. This alternating use of the room by one roommate and then by the other has a limited usefulness when most of the student's activities occur in the room. Apartments will often have the same overall density of occupants, but the layout of the area makes for an important difference in comfort. Apartments have common areas, even if small, in the living room, the dining room, the kitchen, and the bath, where students may go, to seek privacy, or allow their roommate the exclusive use of the bedroom. Dorms likewise have common areas, in the corridors and lounges and baths, but these do not serve the same function. Sommer (1969a) discusses why.

In apartments common areas become part of the individual's personal space as he engages in actions there. In dormitories they do not, generally. The critical difference has to do with how much ownership can be exercised and with how many people it must be shared. Additionally, apartments provide separate rooms, affording visual privacy and enhancing personal space feelings. Dormitory rooms have no such visual screen. Some students create an auditory'screen, and attendant privacy, by spending large amounts of time inside stereo earphones.

The general university goal of closeness between students has been achieved, but not in the manner intended. The feelings about privacy and togetherness are clearly enough expressed by students to those who interview them, yet the message is still not clear. White (1969) asked administrators what they thought the goal and purpose of a dormitory should be. They told her togetherness, intimacy, and an informal life style. Asking that same question of students she found that students wanted to be left alone, and that the dormitory was 
seen as one more institution in a mass society. Surviv depended not upon commitment to residence hall activity, bt avoidance of it altogether. This is analogous to Whyte's findin! about retreatist privatism as the response to mass and alienatir society (1956). The consequences of having no place to ca one's own include alienation, hostility, rootlessness, and mo serious for those who would establish community, a sense c transience, until something better can be found.

Corridors. Sociability is fostered in other ways, in addition 1 the small, crowded, and adjacent rooms that are so unsati factory. Farmer (1964) has been quoted on the lesson togetherness that the gang bathrooms are. Van der Ryn (ar Silverstein, 1967) cites one girl's complaint, that in th dormitory she was unable to luxuriate in a bathtub while st could at home and in the apartment to which she subsequent moved. However, students do not in general complain about th group baths. Wheeler (1968) asked students what were the major complaints about dormitory life. Common baths we not among those complaints.

There are related issues, however, Van der Ryn notes a interesting sex difference in use of corridors. Girls dress to g into the corridor, whereas boys do not. Girls will knock o room doors and wait to be invited in, while boys will knock an walk in. Girls, Van der Ryn speculates, perhaps identify wit their rooms, possibly in accord with various psychoanalyt notions regarding enclosed spaces and entrances (compal Erikson, 1950). Boys, on the other hand, feel no suc differences and are equally comfortable in various stages c dress or undress in their rooms as well as the common corride spaces. In this light, gang bathrooms, which are not intrinsicall a problem, pose more inconveniences for women than for mel Open dormitory visiting policies, as well as an increase in th tendency toward coed corridors, exacerbate this problem an occasionally pose security threats, but these are not reported $b$ users as major problems.

It is interesting to note that virtually no writer has discusse 
the placement of room doors. Room doors open onto the corridors and can face the wall or the door to the opposite room. If doors face each other, then occupants have visual access, or, alternately, lack of visual privacy, when the doors to both opposing rooms are open. Since room temperature and ventilation present a problem, room doors are often left open (Wheeler, 1968). Riker (1956) has noticed that room doors are more likely to be placed opposite than staggered. This placement of room doors means that one more area of behavior, here ventilation, becomes part of the general issue of enforced sociability, when that area need not be. In self-defense students often improvise ingenious and highly original visual screens that still allow for air flow.

Dining. Not all dormitories require or provide meal contracts and dining facilities, but many do. The experience of common dining together is one more part of the togetherness that marks dormitory life. There are many problems with institutional eating, vocally and eloquently expressed in Van der Ryn and Silverstein (1967) and others, but they do not derive from the togetherness of eating. Limited choice, reserved meals, common denominator preparation, fixed hours for eating, failure to reflect missed meals in fee adjustments, and high costs all contribute to a general unpleasantness about mass feeding, but do not derive from the physical layout of the eating area. The Cornell study (Cornell University. News Bureau, 1963), based on user needs as inputs for the design of a new building, learned only that students would like smaller dining areas to create some greater sense intimacy and noninstitutionalism. Wheeler's (1968) investigation also produced no major complaints about the physical facilities provided for dining.

Common dining does provide an informal and shared activity, in which new friends may be made, or old friendships continued. Van der Ryn and Silverstein (1967) cite a personal communication from Sommer, to the effect that round tables are more suited for extant groups, and that rectangular tables lend themselves more to the creation of new acquaintances. 
Sommer (1966a) has amplified those comments, in a discussion of how space designed for many may be monopolized by a few who seat themselves in strategic positions. For maximum flexibility, it would seem that a mixture of various kinds of seating arrangements is ideal. Jencks and Reisman (1962) have impressionistically noted that the size of the table also contributes to the size of the groups formed. They also note that the size of the entire dining area has impact. If it is small, and depends on a relatively rapid turnover of users to accommodate all its patrons, then meals will be shorter and less relaxed. That will contribute to a different, less social mood than a dining area where there are ample spaces for all to relax and expand. The good feelings of dining together may be moved to other parts of the campus, or be excluded from the student's life.

The literature contains little discussion of acoustical treatment of eating areas, although other common areas are reported as presenting noise problems. Eating is often an attempt at relaxation and separation from the day's work activities, and the noise levels will certainly have importance. Noise, haste, crowding, inconvenience, and other environmental characteristics may seem minor factors, but they all contribute to what is often considered the intangible of ambience.

Social interaction. Dormitories, it may be seen, attempt to foster sociability and community. Many of the problems and dissatisfactions that do arise, arise in response to enforced sociability and the absence of opportunity for solitude and privacy. The research evidence that does exist, however, indicates that administrators and designers are not completely out of touch with student needs or expectations and actions. Penn (1967) interviewed. 450 undergraduates at the Madison Campus of the University of Wisconsin. Students there reported that they had planned for some dormitory living when thinking about college. Dormitories, they said, provided an opportunity for meeting people and learning to live with new types of 
people. They provided opportunities for involvement in campus-related academic and extracurricular activities. Thirtythree per cent of the men and $43 \%$ of the women, however, found dormitories to be the least desirable of all possible living arrangements.

Alfert (1966) found some indirect evidence for the success of the apparent intentions for social cohesion and solidarity. In a study of dropout rates in various types of student housing, she found that students in private rooms and boarding houses felt more isolated and had a higher dropout rate than comparable students living in dormitories, fraternities and sororities, coops, and apartments. The latter arrangements were felt to provide more "community." Riker (1956) cites impressionistic evidence from administrators in support of that observation.

Hsia (1968) found that dorm dwellers at the University of Utah preferred off-campus living to dorms, although they preferred their own dorm to others. They reported satisfaction with the way the dormitory facilitated social matters.

Baird (1969) studied students who had filled out the American College Survey upon entering college. Of the 12,000 who did so in a national sample, he selected 2,800 males and 2,900 females at 29 colleges. He found that in their sophomore year, comparing dwellers in dormitories, fraternities and sororities, off-campus apartments, on-campus apartments, offcampus rooms, and home, that on-campus dwellers were more active in campus activities than those living off-campus.

Participation in campus activities may not be the best indicator of successful college experiences, but it seems to go along with factors that are so considered. Stafford and Sommer (1967) compared reactions of 72 freshman girls who lived in dormitories, and 72 who lived in apartments because there was no room in the dorms. Twice as many campus girls as non-campus girls (40\% to $20 \%$ ) were involved in school activities. Four times as many apartment dwellers as dormitory dwellers reported feeling isolated (40\% to $11 \%$ ).

Sommer (1968a) has found that four types of student housing-apartments, high-rise dormitories, temporary housing 
in reconditioned barracks, and cluster halls-were reported as satisfactory. Apartment dwellers, however, reported feeling isolated.

PROXIMITY AND SOCIAL RELATIONS

While sociability and community may be the most commonly expressed goals of the dormitory, the relation of patterns of adjacency and traffic flow seem to lend themselves to environmental programming more than other, larger, aspects of design. Traffic flow would certainly seem to be important in deciding who meets whom, or at least how often, and under what circumstances of casualness. There would seem to be some general concern that residential spaces were not designed too close to nor isolated from other spaces. Festinger et al. (1950) have elaborately spelled out how patterns of adjacency allow for casual meetings, for repetition, and for the beginnings of relationships. Yet as Studer and Stea (1966) have noted, proper environmental programming requires a clear notion of the functions to be performed by that environment. An informal environment is considerably more complex and difficult for programming than a formal one. A residential setting seems the epitome of informal environments, especially when the concern is with casual and chance encounters.

There is surprisingly little research on the effects of proximity. Newcomb $(1961,1943)$ has noted that in the initial stages of the process of meeting new people, in a small and well-defined setting, close neighbors meet each other before they meet those more distantly located. The distances involved in his study were two floors of a seventeen-man boarding house. With small distances and small numbers of students, his work may not be that informative on the effects of propinquity.

The research of Festinger et al. (1950) articulated the concept of functional distance, the distance which must actually be traveled, rather than the sheer physical distance. Thus separate and poorly connected adjacent areas may actually be more functionally distant than remoter areas that are well 
connected. In accord with these concepts, the researchers found that patterns of friendship tended to be defined by adjacency and traffic flow. More interestingly, in terms of functional distance, they found that housing which faced a courtyard often included some houses that were set off to one side, to a greater degree than the other houses in that courtyard. Those houses might even be actually closer to those of an adjacent courtyard. Yet the sociometric choices made by residents of those houses, while fewer because of the isolation, were made within the courtyard those houses faced, rather than the adjacent courtyard.

Festinger et al. studied student housing, but did not consider the same effects of propinquity in a dormitory. Van der Ryn and Silverstein (1967) have acknowledged that factor in social relations with reference to a "nod-line" which separates those who are known well enough to be nodded to, from those who are not.

Wheeler (1968) has examined this factor with more rigor and with greater consequences than a negative research finding. Using students as consultants for dormitory construction, he found that the traditionally designed doubleloaded corridor was considered too noisy. In new construction, the two sides of the corridor were separated by a center area of service facilities, maintainence areas, storage space, gang baths, and the like. That separation reduced the noise, but significant for this discussion, also produced student complaints that the two sides had become isolated from each other. Propinquity clearly has some effect.

Menne and Sinnett (1971), using the traditional research tools and orientations of social psychology, sociometrically studied who would be chosen by students for a friend and for a helper, in male and female corridors. For both sexes adjacency was able to predict for reciprocal choices but not for unreciprocal choices. Roommates were the most likely to be chosen, then near neighbors, then others in the corridor, and finally others. 
Warr (1964) has found that in English halls of residence students are more likely $(p<.001)$ to interact with faculty members in their hall than in other halls. He also found that students were more likely to choose future roommates from people within their corridors than outside of it. It should be noted, however, that a substantial amount (40\%) of choices were made from outside the hall.

The effects of propinquity are confounded by nearness to special facilities, in ways that are not always obvious. Festinger et al. (1950), for example, have noted that two-story apartment houses, with staircases at each end, produce a surprising social pattern. Those living near the staircases were much more likely to know others in the building than those only one apartment away from those staircases. Staircases, a post hoc interpretation pointed out, channel the traffic, so that those adjacent have more contact than those not adjacent. Festinger has been criticized, however, in his treatment of the courtyard houses. Gutman (1966) cites Kuper (1953) as saying that common walls contribute to a major source of friction between neighbors, in public housing in England. Some of the courtyard housing in the MIT study shared a common wall.

The evidence is mixed with reference to dormitory conditions. Warr (1964) studied the effects of placement of rooms adjacent to staircases and found that those rooms received the same number of sociometric choices as the rooms on corridors. In that study, however, staircase rooms were considered particularly attractive, and occupied by upperclassmen. Propinquity here becomes confounded with other factors, and so a pure test of Festinger's finding cannot be made.

Norm Snustad, Director of Housing at the University of Michigan's East Quad, has stated (1971) that social placement and strategic location have considerable importance. The location of resident staff in his dormitory is based on such factors as traffic flow, centrality, and adjacency to staircases and bathrooms. Proper placement, he says, assures that in the normal course of traffic flow, the resident staffer will frequentIy see all the residents so that some natural awareness of each 
other, unlabored by special interest or role prescription, is facilitated.

Wheeler (1968), after finding that two separated banks of student rooms produced socially separated groups, redesigned the next dormitory to avoid that problem. In the final form, the center area was not occupied by facilities used to keep the two banks apart. Rather, that area was designed as a lounge-study area, where people from both sides of the hall could go, with some purposeful activity and facility to draw them, including sound-proofed typing areas and small rooms for other uses. This design met with the most user satisfaction. This research design, it should be noted, involves building three dormitory buildings, at great expense, and with a fairly permanent environmental impact on subsequent generations of students. It is a research design neither accessible nor recommended for all dormitory research.

High-rise and low-rise. High-rise housing is increasingly considered and utilized for dormitory housing, particularly as urban universities with land-acquisition limitations consider housing their students. High-rise is usually defined as being more than five stories, and as such represents a considerable departure from the usual pattern of cottage-like, clustered housing, or small hotel-like housing. As such, there might be considerable differences in the patterns of social relation in the high-risers, as compared to low-risers (see also Bickman et al., this issue).

Wallace (1952) has studied this phenomenon impressionistically, in public housing projects. His major finding was that high-rise housing made it harder to casually go outside. Going outside became a more deliberate act, and was done less frequently. Bland and Schoenauer (1966), and the University Facilities Research Center (1963), both of whom have considered the problem, make no mention of any differences. Sommer (1969b, 1968b) has speculated on the effects. In low-rise housing, he says along with Wallace, residents can more easily and spontaneously drift outside, weather and landscape 
permitting, to relax or study on lawns and plazas. The potentia for outdoor activity has long been recognized in mental hospita design, with specific attention to designing places conducive ts privacy, peaceful relaxation, and perhaps a sense of onenes with nature. With architectural recognition of outdoor space for some purposes, it is particularly surprising that dormitorie have not made use of the opportunity in those areas. De Jong: (1967), writing from the perspective of a landscape architect has echoed Sommer's sentiments.

It may well be that as buildings rise higher, and occupan density increases, increasing amounts of outside area adjacen the building must be taken over for service drives, acces roadways, and the minimal parking that all facilities seem te need. Accordingly less space becomes available for student usi in leisurely pursuits. Additionally, as there are more people space becomes owned by a generalized other, rather that specific neighbors and colleagues with whom it can be shared

High-rise housing necessarily includes elevators. The Uni versity Facilities Research Center (1963) has pointed out tha elevator service considered adequate increases in cost as thi building rises, to such degree as to offset much of the gains ir initially reduced land costs. Conceivably the elevator coule provide a common facility in which to meet new people analagous to toilet or dining facilities. In practice, as Wheele (1968) had discovered, poor elevator service ranked as thi number one complaint in dormitory housing, more annoyin! even than noise.

Low-rise housing serves fewer people, and so should hav more intimate dining facilities. But with maximum kitches efficiency plateauing at service for one thousand, the trend $t_{1}$ combining kitchens becomes dominant, with attendant com bining of dining areas. In response to the demand for mor noninstitutional qualities, however, even large kitchens ar coming to be designed with a series of small satellite cafeterias rather than one mass eating room.

Snustad (1971) has observed that in low-rise walk-ul housing, the top floor tends to develop with more interne 
solidarity and cohesion, and with less interaction with the remainder of the building. This is doubtless due to the inaccessibility of the fourth floor, especially for quick and casual visits, and when potential visitors are tired. Four or five flights can be too much to walk. In high-rise housing, where elevator service is provided, no such isolation because of long staircases will occur. The potential for this change is either positive, with an increase in overall integration through the building, or negative, with the disappearance of a once somewhat more private residence than most.

Dormitories that house more than thirty or forty students generally are divided into smaller units called houses. These are clusters of from twenty to forty students in areas that are usually physically separated from other such houses. In low-rise housing this is simply enough implemented by separate entrances for the separate houses. The overall design is that of a three- or four-story series of semi-attached houses. As houses become high-rise, with one elevator serving all floors and all residents on each floor, the separation based on walls or separate entrances becomes unviable, and a new approach to the house plan must be developed. Some dormitories cluster students in two or three adjacent floors into a single administrative house. Others, where single floors are big enough, will call their administrative unit a floor, and let that unit replace the idea of house. Vertical house plans are favored by tradition, by the potential for skip-stop elevators lelevators that make only one stop for each house, skipping the one or two other floors of that housel, and by the fact that some single floors may simply be too small to constitute a house.

Alternately, Van der Ryn and Silverstein (1967) have noted that the nod-line that defines groups seems to coincide with floor divisions. In a dormitory that had a vertical house plan and then removed the walls that separated the houses, Snustad (1971) found groupings to more naturally form around floors rather than staircases. Riker (1956), in summarizing the impressionistic observations of many administrators, agrees with those assertions. 


\section{STUDY ACTIVITIES}

A large part of a student's activities in college comprises studying of one sort or another. There is some research on hou the physical environment within which studying takes place affects that activity. This is partly reviewed in Hsia (1968).

Bailey (1958) found, in a survey of nine campuses ir Wisconsin, that students spent twenty hours each week studying, on the average. Stoke et al. (1960) found that $70 \%$ o: study time was spent in a student's room, according tc interviews. Sommer and Peterson (1966), using student diaries also reported about $80 \%$ as the amount for student rooms. Hsic (1968: appds. 5) found the figure at the University of Utah tc be about $50 \%$. The figures vary, reflecting either methodologica or academic differences, but they are all indicative of the importance of adequate study conditions in a student's room Hsia (1968), notes that "quiet study conditions" were consid ered a primary factor in accommodations that were rated b) students as satisfactory. Van der Ryn and Silverstein (1967) report a similar result. Two-thirds of those who moved out 0 : the dormitories said that one reason was the search for mork satisfactory study conditions.

The elements of good study conditions have been variously described by many. Stoke et al. (1960), in a study commis. sioned by several small colleges investigating the feasibility anc necessary facilities of merger into a new plant, prepared a listing that embraces most of the conditions cited by others. Ir somewhat abbreviated form they are as follows:

(1) Provision for either solitary study, or study with a minimum o: others;

(2) A place exclusively devoted to study:

(3) Is free from distractions and movements of others;

(4) Is free from noises from such sources as telephones, plumbing, anc typing;

(5) is equipped with personal control of heat, light and ventilation; 
(6) Is adequately equipped with desk and shelf space, and near needed materials;

(7) Has pleasant furnishings, visual decor, and few rules of conduct, if any.

Van der Ryn and Silverstein (1967) also cite the desire for students to be able to interrupt studying by snacking.

This is a lengthy listing of conditions, and it is hard to think of what single facility will satisfy all these requirements. Some facilities are worse than others, and dormitories are worse than most. High student density, varying class schedules, and individual work styles, among other factors, all work to guarantee a generally high level of background noise.

Since student housing generally is maintained by specialized maintenance staffs, many surfaces tend to be flat, shiny and easy to clean. These surfaces are also ideal for reflection rather than absorption of sound. Student rooms likewise are often like echo chambers. Riker (1956) notes that the introduction of sound-deadening window drapes into men's halls was greeted with approval by the residents, notwithstanding the potential feminine overtones in a concern for such frills and extras.

Van der Ryn and Silverstein (1967) found that desks are invariably too small for intensive study, and Farmer (1964) has noted the absence of book storage space. This leads to various improvisations that have been investigated by Sommer and others. Van der Ryn and Silverstein found students typing on the floor, because that surface damped the clatter of keys more than the desk top. Gifford and Sommer (1968) find that many students prefer to study on the bed. It is more comfortable, and allows more space to spread materials out. One source of dissatisfaction with bunk beds is that they limit the usefulness of that space. Gifford and Sommer examined the GPA of bed studiers, and found no difference, contrary to the many administrative warnings about the dangers of studying in bed.

Sommer has even designed his ideal studying furniture, based on his college days. It is essentially a bed, with a crank to adjust the upper part, as in hospital beds. It would have an adjustable 
overhead light, and a ceiling-hanging ashtray. On one side woulc be an adjustable writing arm. He might have added a stand fol holding books and papers, and a cup for pencils, to complete the picture.

Room conditions are not the only parameters of studen 1 satisfaction in rating study-bedrooms for adequacy in studying Estabrook and Sommer (1966) also find personality factors of students are involved. One hundred thirty subjects were giver the Maudsley scale of introversion/extroversion, with upper anc lower thirds separately considered. There was no difference ir the effective study time for each group. Introverts preferrec desks, and hard chairs, while extroverts preferred soft chairs anc couches. Introverts took their study breaks alone $(p<.05)$ while extorverts snacked more $(p<.05)$.

It may be seen that study conditions in dormitories are clearly not ideal. Less clear is the effect of those conditions Grosz and Brandt (1969) studied 87 college freshman, dividec into three equal groups of those living at home, in dormitorie: but who came from the area, and in dormitories and were no. locals. Students were matched on sex and on scores on the American College test. No GPA differences were found. Bairc (1969), in a study already cited, similarly found little differ ences in academic variables, in the groups studied in his nationa sample.

Within a dormitory, conditions for study vary for singles anc doubles. Sommer (1969b) has found that students are much les: likely $(75 \%$ to $25 \%)$ to study if they have a roommate in the room who is not studying. Riker (1956) cites Hansen (1942) a! saying that students in singles have better grades and bette health than students in doubles. The other researchers have found conflicting results. Two is sometimes ideal, and GPA doe: not always discriminate. Perhaps other factors are importan. here, such as intensity of study, reading and note-taking versu: writing, subject area, similarity of roommates in subject area and other factors that are not related to the environmenta implications. 
INDIVIDUALIZATION

Riker and others have cited that one of the often-stated goals that colleges have for students is that of furthering and developing individual potential. This may be done in fairly specific academic discipline areas, or it may be more the total self-actualization that Maslow has discussed. The physical environment has positive and negative potentials for students in this area, as well as the other areas already discussed.

For students this has come to mean undoing the institutional quality of rooms (interchangeable-and universally acceptable). The general process of personalization, coupled with the particular needs and expectations of college students to reject that interchangeable quality, is sharply in contrast with what the university may permit.

Furniture can lend itself to the personalization process, via rearrangements and replacements. Yet loans for dormitory housing which are government backed, for long terms and at low interest, include the costs of built-in furniture, but not movable (and removable) furniture. This loan provision encourages design with built-in furniture, and impedes the personalization that is part of self-development of students and impedes the making of a room into a home for two-thirds or three-quarters of a year.

Built-ins tend to take up less space, thus allowing for smaller rooms to have the same amount of overall usable space. Smaller rooms reduce building costs and thus make dormitories financially competitive. Built-ins also reduce replacement costs. They do so at the cost of comfort and high vacancy rates. Beyond that limitation, however, other problems have been found with becoming comfortable, rather than transient.

Van der Ryn and Silverstein (1967) were told by the students they interviewed that there was no way they could decorate their rooms according to their-tastes. Regulations prohibited taping things to the walls, to prevent damage to the paint, and the one small bulletin board area that was provided was both too small and inconveniently located behind the door. He also 
found that students do not arrange the furniture in their rooms according to how administrators imagine functionality. Girls, he noted, tend to arrange their furniture symmetrically, whereas boys do not. Female students prefer to place beds so that the head is near a corner when they sleep, and male students do not. All students in multiple-occupancy rooms prefer to arrange their desks out of the line of sight of other desks in the room, and generally up against a wall, to reduce the incidence of visual distractions by the movements of others. Students will occasionally move dressers or introduce free-standing screens to further the visual privacy desired for studying or sleeping. None of these options is available in dorms where furniture is built in, or where regulations prohibit moving of furniture.

It is to be noted that furniture has come under special attack by researchers. The reasons for this are not specified, but it may well be that furniture constitutes the major portion of the student's immediate and micro-environment. Other than his roommate, the student's in-room actions are circumscribed by furniture to a greater degree than perhaps any single other element. Additionally, furniture is only slightly explored in the research literature, and builders' catalogs devote only a few pages in their sections on furniture to the special needs, if any, of dormitory study-bedroom facilities. Those catalogs than focus on durability, decor, clean appearance, and the economy of space that is more oriented to reducing the necessary dimensions of rooms than increasing the available living space (Sweet's Division, .1970). Room furniture thus has the joint properties of being perhaps the single most important and least understood factor in the student's environment.

One resolution to this problem is the increasing administrative permitting of students to trade in furniture that they do not want for furniture that they do, in some central housing furniture exchange. This sometimes subject to restoring the room to its original condition when the students leave. Students currently add what they want via rentals, primarily of such extras as televisions and stereos, refrigerators, art prints, and other sundries. Propst, a researcher at Herman Miller Research 
Associates, has suggested (1971) that this system be expanded to allow students to rent all their furniture from the dormitory, or none of it, with attendant savings.

Other minor annoyances cited in the literature are the failure to provide sufficient electrical outlets for the increasingly electrified generation of college students, surfaces with heights that are suitable for typing, adjustable or attractive window shades and drapes, conveniently accessible switches and heat controls, in-room lockable storage areas, and others. All contribute to rising vacancy rates when the off-campus housing that competes with the dormitories has considerably fewer of these limitations.

\section{NONUSER DESIGN FACTORS}

From all that has been said so far, dormitories would seem to have been particularly poorly designed for user needs, presumably in response to overriding other needs. An investigation of these possible other needs is in order. One of these needs is financial.

The University Facilities Research Center (1963) has produced a concise statement of the financial constraints involved in building student housing. The very factors that give rise to the institutional look, namely endlessly similar rooms, identical units within rooms, straight and right-angled corridors, centralized and mass facilities, and acoustically poor insulating materials, are all the factors that reduce architectural and building costs. As noted earlier, the low-interest long-term loans that include the cost of built-in but not movable furniture, contributes to the trend for built-ins.

Double rooms are on an average about 180 square feet, and singles about a hundred. Thus there is a savings of $10 \%$ if students are in doubles. Additional door and window needs for additional rooms, if singles are to be used, raise that cost even more, as does the inclusion of sinks. Triples, of course, are even more economical.

Since all rooms must have windows, large numbers of singles 
make for either increased total outside perimeter, which increases costs, or for long and narrow rooms with the narrow dimension the window side. This becomes unpleasant to live in, and reduces the flexibility of room use.

The financial bind is inescapable. Increased costs for more attractive rooms reduce the financial competitiveness of the dormitory system. When students move out anyway, in a year or two, incentives for improving rooms can fade. The financial bind, however, is further exacerbated by constraints on the operating of housing that are not easily justifiable. Housing costs that students pay cover both operating and capital expenses, whereas tuition costs cover only expenses and not capitalization. Tuition costs to the university are supplemented by endowment income, grants, and monies from other sources. Housing expenses to the university which are passed on to the student do not have that alternate source of funding. Accordingly the competitive possibilities of university housing have built-in and very debilitating limitations. The university, however, with benefit of long-term loans, payable with low interest-without an imperative for profit-has still been unable to provide cheaper accommodations than private builders who have none of these advantages. Administrative costs may make up some of the difference, but it is hard to see how it would make all the difference. Nowhere in the literature is there a detailed discussion of comparative housing costs to the two systems. In closing the mention of financial problems, it may be noted that as students pay for the capital costs in student housing, it would appear that students should have some equity in those properties, more than the advisory voice sometimes afforded them by administrative bodies that determine housing policy.

A second reason for the current design styles grows out of a philosophy of what students are like, and what they expect, even if it may be seen that that philosophy is expensively incorrect. Clark and Trow (1964) have speculated on a typology of student subcultures that Van der Ryn and Silverstein (1967) and others have used to perhaps explain dormitory design. 
Students, they say, can be roughly described by two major parameters: involvement with ideas, and involvement with college life. On these parameters, students can be devided into those involved and those uninvolved. This produces a two by two matrix described in Table 1.

The academically minded are involved with ideas via the traditional medium of school, classes, faculty, papers, and the general content of their classes and their books. The collegiately minded are concerned primarily with what may be called extracurricular activities, in the form of social events and social groupings, sports, making future business contacts based on the old college tie, and so forth. The nonconformist is concerned with ideas and intellectual development, but avoids the organization that the university in its more bureaucratized form has become. His contacts with faculty are more likely to be unexpected and unrelated to specific classes, and highly personalized. The vocationally minded is concerned with the ways in which college can help in subsequent job-hunting. Clark and Trow (1964) who associate each subculture with a campus symbol, give to this group the placement office. It should be noted. that the typology, while plausible and even persuasive, has not been subjected to any systematic investigation.

Van der Ryn and Silverstein (1967) suggest that the dormitory is oriented to the collegiately and less the vocationally minded, because these two comprise the largest section of students. The dormitory would seem clearly not suited to those who are involved with ideas, because of the problems associated with serious study. The collegiate type, with its primary concern for nonacademic social factors, is exactly at home in

TABLE 1

STUDENT SUBCULTURES

\begin{tabular}{lll}
\hline & \multicolumn{2}{c}{ Ideas } \\
\cline { 2 - 3 } College Life & Involved & Uninvolved \\
\hline Involved & Academic & Collegiate \\
Uninvolved & Non-conformist & Vocational \\
\hline
\end{tabular}

SOURCE: Clark and Trow, 1964. 
the environment where socializing is the major activity planned for.

As mentioned, the research literature does not investigate these student types. It may be that historically, when college attendance was more reserved for social elites, the sons of the ruling or climbing classes were content to experience, in their first and in-residence years, the gregarious, anti-individual and anti-intellectual tendencies that were reinforced by the environment. As greater proportions of the population attended college, more diverse needs appeared on campus, and a more varied environment was needed. Jencks and Reisman (1962) have to some degree documented this change in student populations. This includes older students, and if dormitories are to appeal to them, they must do so in part based on the needs that older, usually more serious, students have. It is additionally true that students seem to be maturing earlier, and with earlier maturation ask for more adult and individualized facilities.

Increasing numbers of students create a student housing market substantial enough to justify commercial builders to invest in residential housing facilities that will compete with the campus. With competition comes choice, an exploration of alternatives, and an end to the willingness of students to abide with unsatisfactory conditions.

A third possible source of design factors in dormitories, in addition to finances and students, relates to what may be considered the dormitory's component of the general educational philosophy of residential education. It is this area of educational philosophy that will present the greatest potential for change, when considering how dormitories are to be changed or perpetuated. Van der Ryn and Silverstein (1967) write that of the on-campus residential population at Berkeley, $45 \%$ are freshmen, $26 \%$ are sophomores, $22 \%$ are juniors, and $7 \%$ are seniors. Dormitories are primarily occupied by younger students, and are primarily designed for younger students, indicating something of a fit between what is offered and the needs of the population to which it is offered. The nature of the complaints in part stems from the change that occurs with 
maturation or increasing exposure to college life. In effect, dormitory policy expects students to move to private and individual accommodations after some college exposure. Thus the inadequacies of the dormitory stem not primarily from its mismatch to the students it was intended to serve, but from a new role asked of it that it was much less designed to serve. With the change in student types or student expectations, dormitories must change, in accord with the minor annoyances, to be sure, but also in accord with the new student needs. The alternatives to change can be as serious as the rejection of that component's relevance to the university.

One example of such an alternative may be the Berkeley experience. After student dissatisfaction became so serious and expensive that dormitories were no longer expanded by the Regents, and new construction was halted, students turned to the private housing market in increasing numbers. That market was severe enough to create one of the first student-based Tenants' Unions and rent strikes. The Tenants' Union subsequently became a political force in the city of Berkeley. For all those students who were involved, the experience was doubtless educational, with regard to political and economic realities from which students were once sheltered during their college career. The experience developed community-in the struggle against strongly established forces and the choiceful sharing of living arrangements-out of economic necessity. However, the education was considerably different from that associated with the traditional university context, and seen as more relevant and more desirable.

\section{SUGGESTIONS FOR FUTURE DESIGNS}

One wide-ranging attack on the problems of dormitory housing focuses on listening to students' complaints and redesigning to accord with their needs and requests. User-based studies replace administrative intentions. One example of such a process has been described above (Wheeler, 1968).

Long institutional corridors give way to "jog" corridors, 
corridors which change direction or are simply relocated a fen feet to one side. Sound-porous materials are replaced witr soundproof ones. Room furniture is designed along student based criteria. Movable furniture even allows for some degree 0 . privacy or partial shielding of roommates from each other Large dining halls are divided into smaller ones. Corridor: become carpeted and rooms acquire sound-cushioning drapes Hsia (1968) found that of all the dormitory features, student: reported liking the large windows best. That feature alsc becomes incorporated. Dormitories come equipped now witr libraries, snack bars, and expanded recreational facilities.

As high-rise becomes popular, there is some attempt tc recreate the smaller house atmosphere by designing skip-stor elevators. Lounges are more thoughtfully designed, with facil ities commonly used included to draw students to them, rathe than containing only special furniture and looking like the "furniture showrooms" that are generally unused. Lounge include study or typing areas, televisions, and coffee facilities o small cooking facilities, for example. One study (Brawne, 1967 found that the laundry room and the vending machines wer the true centers of social life that existed outside studen rooms. Accordingly student lounge areas included thos features in subsequent designs.

One aspect of change involves redesign of the area in whict the students spend most of their time, the study-bedroom anc the corridor area adjacent it. Several rooms, up to four or five doubles, will be clustered about a common area that once wa: part of the corridor. This separate area has its own door from the main corridor and is part of a suite of rooms comprising the study-bedrooms. The suite thus allows students to have some quasi-public area that is not their study-bedroom, and is sharec by few enough people to still retain some elements 0 personalizability and territoriality. Costs for this extra spact allocated to students do not become prohibitive, since spact may be taken from the bedrooms because students will spenc less time there and more in their "living room." A group o several suites will still have a common lounge serving twenty 0 
forty people. In effect, the old house plan of bedrooms and common rooms-a two-stage social system-has been replaced by a newer plan with three stages: the bedroom, living room, and lounge.

Within the basic design of suites various arrangements are possible. Some vary the number of rooms, or the mixture of doubles and singles in the suite. Others vary the nature of the common room, adding food preparation facilities, and sometimes adding a partial or full bathroom. Where kitchen and bath are included, the dormitory has in fact become a university-run apartment house.

It has been noted above that apartment dwellers report a greater sense of social isolation than dormitory dwellers. It would be a false saving of the financial viability of the housing investment, if that investment were to be saved at the cost of the unique potential of the university residential system. A more meaningful salvation depends not on minor to moderate increases in convenience and habitability, but rather a fundamental rethinking of how to actualize whatever potential exists in the dormitory.

A second wide-ranging attack on the problems of dormitory housing comes out of this rethinking. Dormitories are not made into super-dorms. Rather, the nature of the separation of living area and working area is changed. Dormitory buildings are modified to include work areas such as classrooms, faculty offices, libraries, labs, study areas, and the other physical elements of the teaching areas. Faculty are encouraged to spend their office hours in the dormitory complex, with occasional apartments provided within the dormitory for resident faculty members. Resident staffers are graduate students in the fields where residents may have interests or majors. In all, there is an attempt to integrate the behaviors, the facilities, and the people involved. An additional factor in this type of design is to house students together who take courses together.

Students who live together in a combined living-learning unit will have more than proximity, dormitory-sponsored activities, and the laundry room as the bases for community. The sharing 
of meaningful, ego-invested activities, and the continued presence of all the various components of student life, all work together to build solidarity and combine the various elements of student life and the college experience. The presence of older faculty, who may be more trusted and more available because of their physically increased proximity, may provide some bridge and continuity with the future. Hsia (1968) reports on research literature that shows increased amounts of conversation among students about school-related materials when they are taking similar courses than when they are not. Jencks and Reisman (1962) point out that the physical integration of classrooms and residence encourages the spillover of ideas and conversations with faculty into areas where students will feel more comfortable than in the corridors of classroom buildings, or the remote offices of the faculty.

Farmer (1964) reports on Stephens College, which has students take classes together, live together, and share the same faculty as advisers. The students report this to be very satisfactory.

Some research evidence is available on the effectiveness of the living-learning unit. Ogden (1969) compared 134 students assigned classes in their residence halls, to 81 students who took classes in the residence halls other than the ones in which they lived. Using a 25-item questionnaire which included five questions on alienation, he found no differences between the groups.

Nudd and Steir (1969) found more encouraging results. In a study of eighteen classes in five subject areas, they found an overall evaluation of "enjoyable." The faculty involved disagreed about the effectivness, however. Classes dealing with factual materials were felt to be less suited than classes involving personal growth and flexibility, to meeting in the lounges of dormitories. The faculty involved were encouraged to experiment with new teaching techniques.

De Coster (1969) studied four groups, in a study of a three-semester project. He found that between a control group of no special treatments and an experimental group that shared 
teachers and counselors, there were no differences between logic grades, GPA, or attrition. The experimentals were happier with their peer relations than the controls, however, and happier with university life. They felt a stronger sense of personal identity, less stress, and reported a greater pleasure associated with learning.

Greenleaf and Lied (1967) studied a group that lived together and took at least one course together from a faculty member assigned to the residence hall in which that group lived. When compared to a control group, there was no GPA difference. However, the group did create a tight-knit living spirit and had an increased likelihood of attending campuswide activities. There was a unity with regard to intellectual concerns, in part traced to a special orientation program. And students reported being pleased with the nature of informal contacts with faculty, even though the faculty reported disappointment at those same contacts.

Pemberton (1968) also evaluated a living-learning experiment. With a total sample of about 170, she found that faculty were more satisfied with those students in the experiment than a comparable control group. The students were called more scholarly and more relaxed about studying. They were reported to be higher than the controls in cultural sophistication, but lower than them in peer independence.

The research results tend to be favorable, eliciting strong endorsement of social and growth matters, and less support in academic indicators. The improvement in community and social matters is not surprising. The failure of GPA to respond is deserving of comment. It may be that the living-learning units are primarily operationalized in response to a sense of alienation. As such they attempt to upgrade student involvement and relationships. Academic matters receive a lower priority. It may be that, as Nudd and Stier (1969) found, some subjects are more conducive to informal environments than others. Their study, it should be noted, concerned classes that were taught in lounges, rather than classrooms built into the dormitory. Sommer, Stoke, and the other researchers who have investigated 
study behavior generally, conclude by saying that students make do with what they have, which may also mean they work about as well as they can, in most circumstances, and that the effects of environment will not show up in the traditional academic indicators. Instead, differences must be sought in areas such as fatigue, satisfaction with work, independently initiated study activities, preferred facilities, and so forth. Accordingly, there would be less indication of impact of living-learning units on grades than on the social and attitudinal characteristics. These attitudinal characteristics may be the critical intervening variables for academic change. Matson (1964) has found that GPA depends on the climate created in each house in a residence system as well as on academic ability. Jencks and Reisman's (1962) study of the Harvard houses is in agreement with this finding.

\section{THE CHANGING NATIONAL CHARACTER}

Change may come about in the design and use of physical facilities that house and shelter students. From a simpler view as a place to sleep (dormire, dormitory), to a place to reside (hall of residence), to a community that combines living and learning activities (residential college), the building has increasingly been the focus of student energies. If the move toward living-learning units is to be continued, it spells the beginning of a new approach to the college experience.

A living-learning unit, complete with a closed circuit tv, video-taped lectures that can be dialed, and computerized library reference facilities, presents many options. If education is to be thought of as a growth experience of all the human faculties, then the ending of the dichotomy, via separation of time and place of work and nonwork, is an important input. The end of that dichotomy may reflect the increasing general social malaise about the artificial separation into what is desired and what is obligated, a malaise that is most vocally articulated by the college-educated young. 
The rise of a residential learning center can be seen as an expression of needs for smallness and intimacy and integration. There seem to be practical upper limits to the size of human associations in which people can comfortably live and relate, and retain a face-to-face sense of community. Multiple involvements in discrete systems can broaden a member's awareness and experience, or can dilute that awareness into a confused and frustrating blur. The demands for useful levels of bigness and complexity, balanced with the smallness that leads to community, continuity, and predictability are hardly exceptional in current mass society, even when presented by college students with regard to their dormitories.

Additionally, the special demands of people who are students, and generally of young persons who are first coming into adulthood and independence, feed into the need for community and manageable bounds of bigness and newness. The circumstances of schooling-carefully defined as a special, transitional, and preparatory time-contribute to a lack of rootedness or identification with the environment. This is complemented and then exacerbated by the nature of the officially provided living conditions. The difficulties in making a meaningful student community are further increased by the suitedness of dormitories to the younger students and the unsuitedness of those buildings to the older ones. The residential community becomes the locus of the inexperienced, the young, the fearful, and those without leadership from slightly older peers.

The dormitory, with its limited facilities and relative inflexible use of them, does not allow for the rapidly shifting and multiple-focused energies of large numbers of young people, people in the beginning stages of the independent self-discovery of personal and social .potential, people of unusual and individualized living styles. The further special needs of students, places to study-quietly, without distraction or discomfort or distance from materials-is also poorly met. The flexibility needed for experimentation with social relations-opportunities for various degrees of closeness, groupness, 
and privacy, are further reduced by the use of doubles as the basic unit, and houses of larger numbers than usually comprise face-to-face groups, as the next unit of social grouping.

The tendency to suites with common areas, built around a common house lounge is a new and needed intermediate step in social relatedness. The suite allows for a two-stage process of meeting new people and controlling the degree of social expectation and demand. A gradualness in increasing the intensity of social relations is surely one part of the needs of people in the first stages of becoming.

The trend to suites also allows for different tasks which must be done, in the various forms of maintenance, with differing degrees of cooperation required, with roommates and then suitemates. Inclusions of baths and kitchens increase the areas for maintenance and increase the areas in which the student can work to be his own master. Van der Ryn and Silverstein (1967) quote one young lady who left the dormitory because she did not like the fact that everything was done for her.

The tendency to suites has its advantages, but as Blake (1956) has noted, decreasing the barriers within a system simultaneously increases the communication within the nolonger-separated areas while decreasing the communication between other, still-separated areas. Suites alone can bring the best and worst of apartment living.

Students have made clear their desire for community, from the needs of young people, of students, and of people. Their concern with ideas and mental development is just as clear. It is the opportunity of the university to recognize those desires in the programming of the student's environment, in architectural as well as other areas. The failure to do so, and the adherence to tradition and a diminishing traditional clientele, promises the drastic reduction in the university's effectiveness and scope. 


\section{REFERENCES}

ALFERT, (1966) "Housing selection, need satisfaction, and dropouts from college." Psych. Reports 19 (August): 183-186.

ALLEN, J., B. COLLINS, C. GEE, and R. NUDD (1964) "Coeducational residence halls. J. of College Student Personnel (December): 8287 .

Architectural Record (1965) "College dormitories." 138 (August): 113-135.

BAILEY, R. P. (1958) "Does dormitory-dwelling provide ideal college life?" Wisconsin J. of Education 90 (May): 10-12.

BAIRD, L. L. (1969) "The effects of college residence groups on students' self-concepts, goals and achievements." Personnel and Guidance J. 47 (June): 1015-1021.

BIRREN, F. (1950) Color psychology and Color Therapy. New York: Mc-Graw-Hill. BLAKE, R. (1956) "Housing architecture and social interaction." Sociometry 19: 135-139.

BLAND, J. and N. SCHOENAUER (1966) University Housing in Canada. Montreal: McGill University.

BRAWNE, M. (1963) "Student living." Architectural Rev. 134 (October): 289-301. BRUST, P. and W. BERNBROCK (1965) "Furniture selection and specifications." Architectural Record 138 (September): 93.

BUSH-BROWN, A. (1957) "Dormitory design: economical housing isn't enough," pp. 176-178 Architectural Record (ed.) Apartments and Dormitories. New York: F. W. Dodge.

Butler, N. M. (1922) Annual Report of the President. New York: Columbia University.

CANTOR, D. (1969) "An intergroup comparison of connotative dimensions in architecture." Environment and Behavior (June): 37-48.

CLARK, B. R. and M. TROW (1964) Determinants of College Students

Subcultures: Berkley: University of Catifornia Center for the Study of Higher Education. (unpublished)

Cornell University News Bureau (1963) The Dont's in Dorm Planning. Ithaca, New York: Cornell University.

CREAN. D. (1970) "The student in residence." Architectural Rev. 147 (April): 286-291.

DE COSTER, D. A. (1969) "Some effects of coordinating classroom and residence hall assignment for college freshmen. A pilot project." Presented at the American Personnel and Guidance Association, Las Vegas, Apri!.

DE JONGE, D. (1967) "Applied psychology." Landscape 17 (Winter): 10-11.

Educational Research Information Clearinghiouse (1970) Student Housing: a Selected Bibliography. Madison: Author, with University of Wisconsin.

ERIKSON, E. (1950) Childhood and Society. New York: W. W. Norton.

ESTABROOK. M., and R. SOMMER (1966) "Study habits of introverts and extroverts." Psych. Reports 19: 750. 
FARMER, M. (1964) "Dormitories," in Educational Facilities Laboratories (ed.) Bricks and Mortarboards. New York: Author.

FESTINGER, L., S. SCHACTER, and K. BACK (1950) Social Pressures in Informal Groups. Stanford: Stanford Univ. Press.

GARDNER, E. (1957) "The sociology of residence halls." J. of National Assn. of Women Deans and Counselors 20 (January): $51-57$.

GEDDES, BRECHER, QUALLS, and CUNNINGHAM (n.d.) Study of Undergraduate Men's Housing Systems. Philadelphia: University of Pennsylvania.

GIFFORD, R., and R. SOMMER (1968) "The desk or the bed." Personnel and Guidance J. 46 (May): 876-878.

GORES. H. B. (1964) A Window to the Future. Stanford: Stanford Univ. Press.

GREENLEAF, E. A. and S. LIED (1969) "Evaluation of the Foster project." Presented at the American Personnel and Guidance Association, Las Vegas.

GROSZ, R. D. and K. BRANDT (1969) "Student residence and academic performance." College and University 44 (Spring): 242-243.

GUTMAN, R. (1966) "Site planning and social behavior." J. of Social Issues 22 (October): 103-116.

HANSEN, M. (1942) "Some factors in the housing of students related to success in college." Ph.D. dissertation. University of Chicago.

HAYES, H. (1932) Planning Residence Halls. New York: Columbia University Teachers College Bureau of Publications.

HIGGS, E. E., M. L. STEWART, and L. WRIGHT (1964) Residence Hall Planning Aids. Washington, D.C.: U.S. Department of Health, Education and Welfare Office of Education, College and University Physical Facilities Series 51004-9A, January.

HSIA, V. W. (1968) "Residence hall environment: a comparative study in architectural psychology." Master's thesis. University of Utah (Salt Lake City).

JENCKS, C. and D. REISMAN (1962) "Patterns of residential education: a case study of Harvard," pp. 731-774 in N. Sanford (ed.) The American College. New York: John Wiley.

KRAMER, R. (1968) Student Housing: a Selected and Annotated Bibliography. Madison: University of Wisconsin Educational Research Information Clearinghouse.

KUPER, L. (1953) Living in Towṇs. London: Cresset.

LIPMAN, A. (1968) "Building and social interaction." Architects J. 147: 23-30.

LOZOFF, M. (1968) "Residential groups and individual development," pp. 255-317 in J. Katz et al. (eds.) No Time for Youth: Growth and Constraint in College Students. San Francisco: Jossey-Bass.

McDOUGALL, W. (1930) "Functions of the endowed university in America," pp. 230-260 in P. A. Schilpp (ed.) Higher Education Faces the Future. New York: Liveright.

Massachusetts Institute of Technology Planning Office (1965) A Program for Undergraduate Men's Housing. Cambridge: MIT Press.

MATSON, R. E. (1964) "A study of the influence of fraternity, residence hall, and off-campus living on students of high, average, and low college potential." J. of National Assn. of Women Deans and Counselors 26 (April): 24-29.

MENNE, J. M. and E. R. SINNETT (1971) "Proximity and social interaction in residence halls." J. of College Student Personnel 9 (January): 26-32. 
Michigan Daily (1971) Series of articles on dormitory security (March and April).

MILLER, E. (1968) "Put a behavioral scientist on the dormitory design team." College and University Business 44 (February): 68-71.

NEWCOMB, T. M. (1961) The Acquaintance Process. New York: Holt, Rinehart \& Winston.

- - (1943) Personality and Social Change. New York: Dryden.

NUDD, T. R. and D. A. STIER (1969) "Do you really want classes taught in your residence hall." J. of National Assn. of Student Personnel Administrators 7 (October): 101-103.

OGDEN, G. B. (1969) "The effects of modified class scheduling on student alienation." J. of National Assn. of Student Personnel Administrators 7 (October): 104-107.

PEMBERTON, C. F. (1968) An Evaluation of the 1967-8 Living-Learning Experiment at the University of Delaware. A University Impact Study. Newark: University of Delaware.

PENN, N. E. (1967) "Student attitudes toward student housing," pp. $1-22$ in American Council of University Housing Officers Research and Information Committee (ed.) Student Housing Research.

PETERSON, R. E. (1968) The Scope of Organized Student Protest in 1967-8. Princeton, N.J.: Educational Testing Service.

Progressive Architecture (1967) "Houses and housing." 48 (May): 100-115.

PROPST, C. (1971) Personal communication with the author.

RASHDALL, H. (1936) The Universities of Europe in the Middle Ages. Oxford: Clarendon.

Real Estate Research Corporation (1965) Analysis Student Housing Market and Alternate University Housing Programs 1963-75. Prepared for the University of California Berkeley Board of Regents.

RIKER, H. C. (1965) College Housing as Learning Centers. Washington, D.C.: American College Personnel Association Student Personnel Series 3.

--- (1961) College Students Live Here: a Study of College Housing. New York: Educational Facilities Laboratories.

- (1956) Planning Functional College Housing. New York: Columbia University Teachers College.

SCHACHNER, N. (1938) Medieval Universities. London: G. Allen \& Unwin.

SNUSTAD, N. (1971) Personal communication with the author.

SOMMER, R. (1970) "The ecology of study areas." Environment and Behavior , 2, 3. (December): $271-280$.

- - (1969a) Personal Space. Englewood Cliffs, N.J.: Prentice-Hall.

- - (1969b) "Study conditions in student residences." J. of College Student Personnel 10 (July): 270-274.

-- (1968a) "Student reactions to four types of residence halls." J. of College Student Personnel 7 (July): 232-237.

- - (1968b) "Going outdoors for study space." Landscape Architecture 58, 3.

--- (1966a) "The ecology of privacy." Library Q. 36: 234-248.

-- $(1966 b)$ "Man's proximate environment." J. of Social Issues 2, 4 (October): 59-70.

- - and P. Peterson (1966) Study Carrels Reexamined. (mimeo) 
STAFFORD, A, and R. SOMMER (1967) "A comparison of on-campus and off-campus living for 14 freshman girls," in American Council of University Housing Officers Research Information Committee (ed.) Student Housing Research.

STEWART, H. O. (1942) Some Social Aspects of Residence Halls for College Women. New York: Professional \& Technical Press.

STOKE, S. M., D. LEWITT, M. OLMSTEAD, and B. SMITH (1960) Student Reaction to Study Facilities. Amherst, Mass.: Committee for New College.

STUDER, R. and D. STEA (1966) "Architectural programming and human behavior." J. of Social Issues 22, 4 (October): 127-136.

Sweet's Division (1971) Sweet's Architectural Catalog File. New York: McGraw-Hill Information Systems.

University Facilities Research Center (1963) High-rise or Low-Rise. Madison. Wisconsin: Educational Facilities Laboratories.

University of California Department of Physical Planning and Construction (1969) User Requirements. Berkeley: Educational Facilities Laboratories.

VAN DER RYN, S. and M. SILVERSTEIN (1967) Dorms at Berkeley: an Environmental Analysis. New York: Educational Facilities Laboratories.

WAKEFIELD, H. E. and B. C. BLOOMFIELD (1969) Student Housing Bibliography, 1968. Madison, Wisconsin: Educational Research Information Clearing House and Educational Facilities Laboratories.

WALKER, E. H. (1968) Student housing consultant. Student Housing Study. Guelph, Ontario: University of Guelph.

WALLACE, A.F.C. (1952) Housing and Social Structure. Philadelphia: Philadelphia Housing Authority.

WARR, P. B. (1964) "Attitudes and behaviors in a hall of residence." Universities $Q$. 199LO (December): 56-68.

WHEELER, L. (1968) Behavioral Research for Architectural Planning and Design. Terre Haute, Indiana: Ewing Miller Associates. (Also found in "A behavioral slide rule." Interiors 127, 5 (December 1967): 106-107.)

WHITE, J. E. (1969) "Style of life and student personnel policy in college residence halls." J. of National Assn. of Women Deans and Counselors 32 (Spring): 123-125.

WHYTE, W. H. (1956) The Organization Man. New York: Simon \& Schuster. 